\title{
ENGLISH LEARNING ASSISTANCE USING INTERACTIVE MEDIA FOR CHILDREN IN ORGANIZATIONS IN WAJO DISTRICT
}

\author{
Satriani $1^{*}$ \\ Syahrun Adzim² \\ 1,2 Institut Agama Islam As'adiyah Sengkang, Sengkang, Indonesia \\ satriani200894@gmail.com ${ }^{1^{*}}$ \\ syahrunadzim@gmail.com ${ }^{2}$ )
}

Keywords: [Accompaniment, Orphanage, Scrabble, English Vocabulary]

Published by:

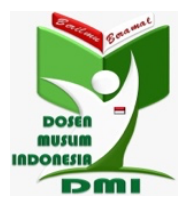

Copyright (C) 2021 The Author(s)

This article is licensed under CC BY 4.0 License
Abstract: The Lecturer Team of the IAI As'Adiyah Tadris English Study Program provided assistance in studying English utilizing interactive media at the Wajo Regency Orphanage. The goal of this activity is to increase participants' enthusiasm in learning English by making it more appealing to them. It is intended that through utilizing interactive media, participants would be able to increase their ability to accurately use English terminology. Scrabble is the interactive medium utilized to provide this aid. This activity's data gathering comprises the following: (1) performance test questions to determine the number of participants who have mastered the vocabulary; the test is completed separately by each participant and presented at the conclusion of the learning material. (2) field notes, which involve documenting the English learning process and photographing activities both before and during the action. Based on the mentoring activities that have been completed, it can be concluded that the participants' attitudes have shifted from being less active, unenthusiastic, and less involved to being more active, enthusiastic, and willing to collaborate collaboratively during the mentoring activity, resulting in an increase in the participants' English vocabulary mastery skills.

\section{(cc) BY}




\section{Introduction}

According to Law Number 23 of 2002 concerning Child Protection, it is stated that every child has the right to live, grow, develop, and participate optimally in accordance with human dignity and protection, and to receive protection from violence and discrimination, for the realization of quality Indonesian children who are noble and prosperous (Siregar \& Rahmi, 2019; Kusuma, 2021).

Conditions, as described above, are the dream of a nation that wants to progress and be dynamic. But the reality in society is that not all children's needs can be met. Among them, there are those who do not get their rights and face various obstacles so that they become neglected. This occurs, among others, in children born to families experiencing divisions, poor families whose lives are deprived, or children who have lost one or both parents (Schmalzbauer, 2004; Evans, 2004; Bryceson, \& Vuorela, 2020).

Childhood is a golden period for a child to continue to learn and dream. Therefore, every child should be given the opportunity to dream as a reference for their future (Putnam, 2016; Johnson, 2019; Gibson \& Ewing, 2020; Bang, 2020). But often, the facts are still different. There are still many children who are willing to learn, but they do not have the opportunity to learn like their other friends. In particular, orphans who do not have sufficient donors and assistance to sustain their opportunities to continue learning and dreaming.

The main focus of this orphanage is to help, support, foster, and provide facilities for children in a community (dormitory). In this place, they are also nurtured, taught, and educated about how to live a normal life, just like their other friends, about the importance of love, morality, and knowledge. For that, they are also sent to college. For now, of the 27 foster children at the orphanage, 11 are elementary school students, 7 are junior high school students, and 4 are high school students. Under the guidance of four caregivers, these children are nurtured both morally and academically. With the educational background of pesantren, the caregivers have no difficulty when dealing with moral development. It's just that they have difficulty guiding the children to learn, especially English. Therefore, our team is interested in helping the caregivers of the orphanage by providing assistance in learning English using interactive media. As has been done by several previous studies and community service related to learning media (Lopez, 2010; Astuti et al., 2020; Suardi et al., 2021; AR et al., 2021).

The interactive medium that will be used in this mentoring is Scrabble. Scrabble is a word-making game. Scrabble can be played by everyone, from children to adults. The Scrabble game aims to improve vocabulary, especially English vocabulary (Levent, 2009; Zhonggen, 2018).

Scrabble, according to Sadiman (2008), is a picture (graphic) that is tailored to the needs of pupils who prefer visual learning, quickness, and responsiveness. Image media can be used in groups of two to ten individuals or independently. This intriguing English learning mentoring approach is supposed to assist orphanage caretakers and children in motivating themselves and maximizing their English ability. 


\section{Implementation Method}

The implementation of the activity involved two parties: (1) the community service implementation team and (2) the Wajo Regency Orphanage.

This mentoring activity is carried out in four stages: (1) preparation phase, (2) implementation phase, (3) evaluation, and (4) report preparation. The preparatory stage of this community service activity includes completing administrative activities at the IAI As'adiyah Sengkang English Tadris Study Program and at the Wajo Regency Orphanage as mentoring partners who are involved. This stage also includes observation of the location where the mentoring activities are carried out. Before starting the community service activities that have been prepared, the implementing team contacted the relevant parties from the orphanage to agree on activities, including scheduling activities, forms of activities, and activity participants. The implementation team went to the orphanage on Thursday, May 18, 2019 to carry out observations. Both parties coordinate in the planning and implementation of activities.

The implementation of the activity involves both parties: (1) the party from the Community Service implementation team and (2) the party from the orphanage. At this stage is the implementation of assistance in learning English using interactive media for children.

In addition, mentoring activities are carried out classically and in groups. In the early stages, children are given reading material about the importance of learning English and tips on learning English that are fun for them. After that, they were divided into several small groups, each of which was accompanied by a companion lecturer. They learn English vocabulary by using interactive media such as scrabble.

At this stage, the orphanage children as mentoring participants are enthusiastic and active in playing scrabble. They seemed enthusiastic about paying attention to the suggestions and recommendations made by the accompanying lecturers. Mentorship is carried out for 2.5 hours and ends with quizzes and the distribution of door prizes for participants who can answer questions posed by the accompanying lecturer.

This community service activity is evaluated based on the achievement of the activity objectives. This community service activity includes material delivery, class discussions, group discussions, and quizzes. From the observations made during the mentoring activity, the participants were enthusiastic and more motivated to learn English. With this mentoring activity, it is hoped that the ability of participants to learn English will increase so that they can take advantage of it in the future.

The preparation of activity reports is carried out to provide a comprehensive picture of the ongoing process of activities from the beginning to the end of the activity. The report was prepared by the implementing team for community service activities for the IAI As'adiyah Sengkang English Tadris study program. The format of the proposal and the preparation of the report follow the systematic preparation of proposals and activity reports.

\section{Results and Discussion}

The interactive medium used in this mentoring is Scrabble. Scrabble is a wordmaking game. Scrabble can be played by everyone, from children to adults. The Scrabble 
game aims to improve vocabulary, especially English vocabulary ((Levent, 2009; Zhonggen, 2018).

Scrabble is a board game played by two to four people whose aim is to form words using the available letters (Halpern \& Wai, 2007; Tuffiash et al., 2007; Kobzeva, 2015). They are given a score on a $15 \times 15$ square board. Holden (2012) considers Scrabble a game that tests luck in determining which players have good or bad letters (Holden, 2012). The statement above explains that the game of scrabble relies on a good arrangement of letters to create the word with the highest score. Furthermore, luck and the ability to play Scrabble are determined by the ability to arrange letters into a word on a board so that they get a score (Holden, 2012).

The game "Scrabble" was created by Alfred Mosher Butts. Butts is an architect from Poughkeepsie, New York (Fatsis, 2001; Edley \& Williams, 2009; Novikova \& Beskrovnaya, 2015). He created a board game from three different categories of games. First, numbers games like "Dice and Bingo", then moving games like chess and checkers, and word games like anagrams. Based on these three categories, Butts tries to make a game that sharpens thinking skills and also the ability to determine opportunities. Then, Butts combines the characteristics of anagram games with crossword puzzles. The game was named Lexiko, which was later renamed Criss Cross Words. Butts meets James Brunot, a toy-loving entrepreneur who is captivated by the concept. The two of them worked together to design and improve the rules of the game Criss Cross Words. In 1948, a game called "Scrabble" was introduced in a collaboration between Alfred Mosher Butts and James Brunot (Tuffiash et al., 2007). The game "Scrabble" has a complete list of tournament rules published in the Official Tournament Rules document (Indriana, 2011).

The game "Scrabble" has a complete list of tournament rules published in the Official Tournament Document. Some of the rules of thumb used during the game and scoring of "Scrabble" are: (1) On the first turn, the player must place two or more letters that form a word. vertically or horizontally with one of the letters in the center square of the board. The middlebox on the board is a double word score bonus box. (2) The game continues with the next player adding one or more letters to form a new word or word. (3) All words added must touch previously made words and must form a word wherever the words already on the board are touched. (4) All words formed in one turn will be counted in value. (5) The value obtained for each turn is the sum of all the letter values in the words formed or modified in that turn plus the bonus value obtained from the bonus box. (6) The double letter score box (dark blue) makes the value of a letter placed in the box triple. (7) The double word score box (pink color) doubles the value of a word that is formed when one of the letters that make it up is placed in the box. (8) The triple word score box (in red) multiplies three times the value of a word that is formed when one of the letters forming it is placed in the box. (9) The assessment of the double letter score and triple letter score takes precedence over the double word score and triple word score in the assessment of one player's turn. (10) If a word formed passes through two double word score boxes, the value of the word is multiplied by four. (11). If a word is formed and passes through two triple word score boxes, the value of the word is multiplied by nine. (12). The bonus box can only be used once. At the turn of the squares, a word is skipped for the first time. (13) If two or more words use the same letter, and the letter is in the bonus box, the bonus applies to all words formed, and (14) if a player uses all seven letters in one turn, then the player gets a bonus of 50 points. 
The following types of data are collected in this activity: (1) performance test questions, which are used to determine the number of participants who have mastered the vocabulary. (1) field notes, which are kept by documenting the English learning process and taking images of activities during the teaching and learning process both before and during the action, and (2) individual tests, which are given at the end of the learning material.

\section{Conclusions}

The achievement of the activity objectives is used to evaluate this community service activity (PKM). Material distribution, class talks, group discussions, and quizzes are all part of this community service activity. During the mentoring activity, the participants appeared to be more passionate and driven to learn English, according to the observations. It is intended that by participating in this mentorship activity, the participants' capacity to learn English will improve, allowing them to apply it in the future. Based on the results of the PKM, it can be concluded that participants' attitudes have shifted from being less active, less enthusiastic, and less involved in the mentoring activity to being more active, enthusiastic, and willing to collaborate collaboratively during the mentoring activity, resulting in an increase in their ability to master English vocabulary. Throughout the mentoring, there was an active interaction process between the presenters and the participants.

\section{Refereces}

AR, R. A., Mahmud, N., \& Amin, N. (2021). WORKSHOP PENGEMBANGAN MEDIA PEMBELAJARAN BERBASIS MULTIMEDIA BAGI GURU SDN INP 055 KANDEAPI. Jurnal Abdimas Indonesia, 1(3), 46-52.

Astuti, L., Wihardi, Y., \& Rochintaniawati, D. (2020). The Development of Web-Based Learning Using Interactive Media for Science Learning on Levers in Human Body Topic. Journal of Science Learning, 3(2), 89-98.

Bang, M. (2020). Learning on the move toward just, sustainable, and culturally thriving futures. Cognition and Instruction, 38(3), 434-444.

Bryceson, D. F., \& Vuorela, U. (2020). Transnational families in the twenty-first century (pp. 3-30). Routledge.

Edley, J., \& Williams, J. (2009). Everything Scrabble. Simon and Schuster.

Evans, G. W. (2004). The environment of childhood poverty. American psychologist, 59(2), 77.

Fatsis, S. (2001). Word freak: Heartbreak, triumph, genius, and obsession in the world of competitive Scrabble players. HMH.

Gibson, R., \& Ewing, R. (2020). Transforming the curriculum through the arts. Springer International Publishing.

Halpern, D. F., \& Wai, J. (2007). The world of competitive Scrabble: Novice and expert differences in visuopatial and verbal abilities. Journal of Experimental Psychology: Applied, 13(2), 79. 
Holden, S. (2012). The scrabble player's handbook. United States and Canada: Hasbro Inc. Indriana, D. (2011) Ragam Alat Bantu Media Pengajaran. Yogyakarta: Diva Press.

Johnson, R. C. (2019). Children of the dream: Why school integration works. Hachette UK.

Kobzeva, N. (2015). Scrabble as a tool for engineering students' critical thinking skills development. Procedia-Social and Behavioral Sciences, 182, 369-374.

Kusuma, A. A. (2021). Exploitation of Children Through Social Media in A Legal Perspective of Child Protection. In Proceeding International Conference of Innovation Science, Technology, Education, Children and Health (Vol. 1, No. 1).

Levent, U. Z. U. N. (2009). An evaluative checklist for computer games used for foreign language vocabulary learning and practice: VocaWord sample. Novitas-Royal, 3(1).

López, O. S. (2010). The digital learning classroom: Improving English language learners' academic success in mathematics and reading using interactive whiteboard technology. Computers \& Education, 54(4), 901-915.

Novikova, V., \& Beskrovnaya, L. (2015). Smart edutainment as a way of enhancing student's motivation (on the example of board games). In Smart Education and Smart e-Learning (pp. 69-79). Springer, Cham.

Putnam, R. D. (2016). Our kids: The American dream in crisis. Simon and Schuster.

Sadiman, A. (2008). Media pendidikan, pengertian, pengembangan, dan pemanfaatannya. Jakarta: Raja Grafindo Persada.

Schmalzbauer, L. (2004). Searching for wages and mothering from afar: The case of Honduran transnational families. Journal of marriage and family, 66(5), 1317-1331.

Siregar, H., \& Rahmi, A. (2019). Punishment Analysis at School Based on Article 54 of the Child Protection Act in Law Number 35 of 2014. Budapest International Research and Critics in Linguistics and Education (BirLE) Journal, 2(3), 542-549.

Suardi, S., Upa, R., \& Pilu, R. (2021). REVITALISASI KAPASITAS GURUBAHASA INGGRIS DALAM AKTIVITAS PEMBELAJARAN REFLEKTIF BERBASIS TRANSCRIPT BASEDLESSON ANALYSIS (TBLA) DALAM PERENCANAAN PEMBELAJARAN (PLANNING). Jurnal Abdimas Indonesia, 1(1), 62-69.

Tuffiash, M., Roring, R. W., \& Ericsson, K. A. (2007). Expert performance in SCRABBLE: implications for the study of the structure and acquisition of complex skills. Journal of Experimental Psychology: Applied, 13(3), 124.

Zhonggen, Y. (2018). Differences in serious game-aided and traditional English vocabulary acquisition. Computers \& Education, 127, 214-232. 